\title{
Clinical Predictors of Obesity Hypoventilation Syndrome in Obese Subjects With Obstructive Sleep Apnea
}

\author{
Zuleyha Bingol MD, Aylin Pıhtılı MD, Penbe Cagatay PhD, Gulfer Okumus MD, \\ and Esen Kiyan MD
}

\begin{abstract}
BACKGROUND: Arterial blood gas (ABG) analysis is not a routine test in sleep laboratories due to its invasive nature. Therefore, the diagnosis of obesity hypoventilation syndrome (OHS) is underestimated. We aimed to evaluate the differences in subjects with OHS and pure obstructive sleep apnea (OSA) and to determine clinical predictors of OHS in obese subjects. METHODS: Demographics, body mass index (BMI), Epworth Sleepiness Scale score, polysomnographic data, ABG, spirometric measurements, and serum bicarbonate levels were recorded. RESULTS: Of 152 obese subjects with OSA ( 79 females/73 males, mean age of $50.3 \pm 10.6 \mathrm{y}, \mathrm{BMI}$ of $40.1 \pm 5.6 \mathrm{~kg} / \mathrm{m}^{2}$, $51.9 \%$ with severe OSA), $42.1 \%(n=64)$ had OHS. Subjects with OHS had higher BMI $(P=.02)$, neck circumference $(P<.001)$, waist circumference $(P<.001)$, waist/hip ratio $(P=.02)$, Epworth Sleepiness Scale scores $(P=.036)$, ABG and serum bicarbonate levels $(P<.001)$, apnea-hypopnea index $(P=.01)$, oxygen desaturation index $(P<.001)$, and total sleep time with $\mathrm{S}_{\mathrm{pO}_{2}}<90 \%$ $(P<.001)$ compared with subjects with pure OSA $(n=88)$. They also had lower daytime $\mathrm{P}_{\mathrm{aO}_{2}}$ $(P<.001)$, sleep efficiency $(P=.032)$, mean $\mathrm{S}_{\mathrm{pO}_{2}}(P<.001)$, and nadir $\mathrm{S}_{\mathrm{pO}_{2}}(P<.001)$. Serum bicarbonate levels and nadir $\mathrm{S}_{\mathrm{pO}_{2}}$ were the only independent predictive factors for OHS. A serum bicarbonate level of $\geq 27 \mathrm{mmol} / \mathrm{L}$ as the cutoff gives a satisfactory discrimination for the diagnosis of OHS (sensitivity of $76.6 \%$, specificity of $74.6 \%$, positive predictive value of $54.5 \%$, negative predictive value of $88.9 \%$ ). A nadir $\mathrm{S}_{\mathrm{pO}_{2}}$ of $<\mathbf{8 0 \%}$ as the cutoff gives a satisfactory discrimination for the diagnosis of OHS (sensitivity of $82.8 \%$, specificity of $54.5 \%$, positive predictive value of $56.9 \%$, negative predictive value of $81.4 \%$ ). When we used a serum bicarbonate level of $\geq 27 \mathrm{mmol} / \mathrm{L}$ and/or a nadir $\mathrm{S}_{\mathrm{pO}_{2}}$ of $<80 \%$ as a screening measure, only 3 of 64 subjects with OHS were missed. CONCLUSIONS: Serum bicarbonate level and nadir saturation were independent predictive factors for the diagnosis of OHS. Key words: hypercapnia; nadir saturation; obesity; obesity hypoventilation syndrome; obstructive sleep apnea; serum bicarbonate. [Respir Care 2015;60(5):666-672. ( 2015 Daedalus Enterprises]
\end{abstract}

\section{Introduction}

Obesity hypoventilation syndrome (OHS) is characterized by alveolar hypoventilation, severe sleep-disordered breathing, abnormal pulmonary mechanics, hypersomnolence, and multiple comorbidities. ${ }^{1,2}$ Patients with OHS have higher morbidity, lower quality of life, more healthcare expenses, greater risk of pulmonary hypertension, and higher mortality compared with eucapnic obese patients with or without obstructive sleep apnea (OSA). ${ }^{3-6}$ Diagnosis of OHS requires arterial blood gas (ABG) analysis, but ABG analysis is not routinely performed in sleep laboratories due to its invasive nature. Therefore, OHS is

Correspondence: Esen Kıyan MD, Gogus Hastaliklari Anabilim Dali, Istanbul Tip Fakultesi, Istanbul Universitesi, 34360 Capa/Istanbul, Turkiye. E-mail: kiyanesen@gmail.com.

DOI: $10.4187 /$ respcare. 03733 


\section{PREDICTORS OF OHS IN OSA}

often unrecognized. Daytime hypercapnia in patients with OSA has been reported at $10-38 \%$, and prevalence increases with rising body mass index (BMI). ${ }^{2,7-14}$ Most patients with OHS have coexisting OSA. ${ }^{15}$ As patients with OHS have a worse prognosis than patients with pure OSA and use more health-care resources, understanding the clinical characteristics of OHS is important. In this study, we therefore aimed to determine the predictors of OHS in class II and III obese (BMI $\geq 35 \mathrm{~kg} / \mathrm{m}^{2}$ ) subjects with OSA.

\section{Methods}

This prospective study was conducted in the Istanbul Faculty of Medicine of Istanbul University from January 2013 to January 2014. The subjects voluntarily gave their informed written consent. The study was carried out according to the principles of the Helsinki Declaration and was approved by the Istanbul Faculty of Medicine institutional board (2013/381).

We studied all consecutive subjects with class II and III obesity (BMI $\geq 35 \mathrm{~kg} / \mathrm{m}^{2}$ ) who were admitted to the sleep laboratory because of a clinical suspicion of OSA from January 2013 to January 2014. The exclusion criteria were a diagnosis of neuromuscular disease, chest wall disease, kyphoscoliosis, diaphragmatic paralysis, obstructive or restrictive pulmonary diseases, severe hypothyroidism, congestive heart failure, or renal failure; receiving diuretic treatment; total sleep time of $<4 \mathrm{~h}$ on polysomnography; drug use affecting sleep architecture (benzodiazepine, narcotic drugs); and failure to perform spirometry.

The demographics, characteristic symptoms of OSA (snoring, witnessed apnea, excessive daytime sleepiness), anthropometric measurements, BMI, and comorbidities were recorded. BMI was calculated using the formula of Khosla and Lowe ${ }^{16}$ : weight $(\mathrm{kg}) /$ height $^{2}\left(\mathrm{~m}^{2}\right)$. Neck circumference was measured at the level of the cricothyroid membrane. Waist circumference was measured from the midpoint between the top of the iliac crest and the lower margin of the last palpable rib in the midaxillary line. Hip circumference was measured around the widest portion of the buttocks. The Epworth Sleepiness Scale (ESS) was used to measure daytime sleepiness. An ESS score of $\geq 10$ was considered to be excessive daytime sleepiness. All subjects underwent spirometry, daytime $\mathrm{ABG}$ analysis, and all-night polysomnography. Spirometry (ZAN 74N, nSpire Health, Sydney, Australia) was performed according to approved standards. ${ }^{17} \mathrm{FEV}_{1}$ and $\mathrm{FVC}$ were recorded as percent of predicted. $\mathrm{ABG}$ analysis was performed on room air after 15 min of rest using an ABL 5 blood gas analyzer (Radiometer, Brønshøj, Denmark) in the morning before polysomnography. Serum bicarbonate levels were measured (Cobas 6000, Roche Diagnostics, Ibaraki, Japan) in the morning on the same day of polysomnography.

\section{QUICK LOOK}

\section{Current knowledge}

Obesity hypoventilation syndrome (OHS) is characterized by alveolar hypoventilation, severe sleepdisordered breathing, hypersomnolence, and multiple comorbidities. Subjects with OHS have higher morbidity, lower quality of life, greater health-care expenses, and a higher risk of pulmonary hypertension and mortality compared with eucapnic obese subjects. The diagnosis of OHS requires blood gas analysis, a procedure not always available in a sleep lab.

\section{What this paper contributes to our knowledge}

OHS subjects had higher body mass index, waist circumference, waist/hip ratio, and bicarbonate levels and lower daytime oxygenation. Sleep efficiency and nadir oxygen saturation were also lower with OHS compared with sleep apnea alone. Serum bicarbonate levels $\geq 27 \mathrm{mmol} / \mathrm{L}$ and nadir oxygen saturation of $<80 \%$ provided a satisfactory discrimination for the diagnosis of OHS.

\section{Assessment of Polysomnographic Findings}

All-night polysomnography was performed on all subjects. Polysomnography included recording of electroencephalogram (central and occipital), electrooculogram, submental and pretibial electromyography, oronasal flow (thermistor and nasal pressure transducer), thoracoabdominal movements (abdominal and thoracic strain gauges), and $\mathrm{S}_{\mathrm{pO}_{2}}{ }^{18}$ Sleep stages and respiratory events were scored according to the American Academy of Sleep Medicine 2007 guidelines. ${ }^{19}$ Obstructive apnea was defined as a cessation of air flow of $\geq 90 \%$ compared with baseline for $\geq 10 \mathrm{~s}$ while there was evidence of persistent respiratory effort. Hypopnea was defined as an amplitude reduction of $\geq 30 \%$ in air flow for $\geq 10 \mathrm{~s}$ that was associated with an oxygen desaturation of $\geq 3 \%$ and arousal. ${ }^{19}$ Polysomnographic records were scored by a trained technician and interpreted by a sleep specialist. OSA was diagnosed if the apnea-hypopnea index (AHI) was $\geq 5 / \mathrm{h}$ with the presence of clinical symptoms or if AHI was $\geq 15 / \mathrm{h}$ without any symptoms. OSA severity was graded as mild (AHI $=5$ $14 / \mathrm{h})$, moderate $(\mathrm{AHI}=15-29 / \mathrm{h})$, or severe $(\mathrm{AHI} \geq 30 /$ h). 19,20 OHS was defined as a combination of obesity $\left(\mathrm{BMI} \geq 30 \mathrm{~kg} / \mathrm{m}^{2}\right)$, daytime hypercapnia $\left(\mathrm{P}_{\mathrm{aCO}}>45 \mathrm{~mm}\right.$ $\mathrm{Hg}$ ), and sleep-disordered breathing in the absence of other known causes of hypercapnia. ${ }^{21}$ OSA subjects without daytime hypercapnia are referred to as pure OSA. 


\section{PREDICTORS OF OHS IN OSA}

\section{Statistical Analysis}

Statistical analysis was done using the SPSS 17.0 pocket program (SPSS, Chicago, Illinois). Descriptive values were given as mean $\pm \mathrm{SD}$. Categorical variables were expressed as the number of cases and percentages. The KolmogorovSmirnov test was used to identify normal distribution of the data. For comparison of normally distributed variables, the Student $t$ test was used, whereas the Mann-Whitney $U$ test was used for comparison of variables without normal distributions. Comparison of categorical variables was performed using the chi-square test. All data are presented as mean $\pm \mathrm{SD} . P \leq .05$ was considered to be statistically significant. The Pearson correlation coefficient was used to examine the relationship between the polysomnographic data, ABG, spirometric measurements, and serum bicarbonate levels. Logistic regression analysis was performed to determine the related factors of OHS (AHI, BMI, oxygen desaturation index [ODI], serum bicarbonate levels, sleep time with $\mathrm{S}_{\mathrm{pO}_{2}}<90 \%$, nadir $\mathrm{S}_{\mathrm{pO}_{2}}$ ). The area under the receiver operating characteristic curve for serum bicarbonate levels was analyzed to determine a cutoff level of bicarbonate for identifying OHS. To assess the predictive performance of serum bicarbonate levels, multiple $2 \times 2$ contingency tables were used to calculate sensitivity, specificity, and positive and negative predictive values.

\section{Results}

A total of 165 class II and III obese subjects were enrolled in the study. Thirteen subjects with AHI $<5 / \mathrm{h}$ were excluded from the study. The remaining 152 subjects (79 females, 73 males, mean age of $50.3 \pm 10.6 \mathrm{y}$, BMI of $\left.40.1 \pm 5.6 \mathrm{~kg} / \mathrm{m}^{2}\right)$ with OSA $(51.9 \%$ severe, $28.9 \%$ moderate, $19 \%$ mild) were evaluated. For 152 subjects, the mean total sleep time was $432.4 \pm 64 \mathrm{~min}$, the sleep efficiency percentage was $84 \pm 10 \%$, stage I-II sleep was $69.8 \pm 15.3 \%$, stage III sleep was $20.9 \pm 12.7 \%$, and rapid eye movement sleep was $9.4 \pm 6.8 \%$. The mean arousal index was $23.2 \pm 16.0 / \mathrm{h}$; the arousal index was $>10$ in $80.2 \%(n=122)$ of the subjects. The AHI of all subjects was $40.2 \pm 27.1 / \mathrm{h}$ (range of 5.2-118/h). The ODI was $43.3 \pm 30.3 / \mathrm{h}$ (range of $2-125 / \mathrm{h}$ ). The mean $\mathrm{S}_{\mathrm{pO}_{2}}$ was $92.6 \pm 5.7 \%$, and the nadir $\mathrm{S}_{\mathrm{pO}_{2}}$ was $73.2 \pm 15.6 \%$. The percentage of total sleep time with $\mathrm{S}_{\mathrm{pO}_{2}}<90 \%$ was $19.5 \pm 25.9 \%$.

Of 152 subjects with OSA, 88 had a diagnosis of pure OSA without hypercapnia, and 64 had a diagnosis of OHS (42.1\%). For the pure OSA group, $45.4 \%$ had severe, $35.2 \%$ had moderate, and $19.3 \%$ had mild OSA. For the OHS group, $60.9 \%$ had severe, $20.3 \%$ had moderate, and $18.7 \%$ had mild OSA. Demographics, spirometric measurements, ABG analysis results, ESS scores, and serum bicarbonate levels of the OHS and pure OSA groups are given in Table 1. BMI $(P=.02)$, neck circumference $(P<.001)$, waist circumference $(P<.001)$, waist/hip ratio $(P=.02)$, ESS scores $(P=.036)$, daytime ABG bicarbonate levels $(P<.001)$, and serum bicarbonate levels $(P<.001)$ were significantly higher, whereas daytime $\mathrm{P}_{a \mathrm{O}}$ was significantly lower $(P<.001)$ in subjects with OHS.

Nearly all subjects (148/152) had current echocardiography, but systolic pulmonary arterial pressures could be measured in 107 of them. Pulmonary arterial pressures was similar in the OHS and pure OSA groups $(30.8 \pm 5.7$ vs $29.6 \pm 5.4 \mathrm{~mm} \mathrm{Hg}, P=.29)$. Of 107 subjects, $23.4 \%$ $(n=25)$ had pulmonary arterial pressures $\geq 35 \mathrm{~mm} \mathrm{Hg}$ (range of $35-52 \mathrm{~mm} \mathrm{Hg}$ ). The frequency of subjects with pulmonary arterial pressures $\geq 35 \mathrm{~mm} \mathrm{Hg}$ was also similar in both groups $(21.3 \%$ vs $19.7 \%, P=.63)$. The right ventricle diameter was significantly higher in the OHS group than in the pure OSA group $(2.86 \pm 0.33 \mathrm{~cm}$ vs $2.71 \pm 0.26 \mathrm{~cm}, P=.003$ ).

Polysomnographic data for the OHS and pure OSA groups are given in Table 2. The AHI $(P=.01)$, ODI $(P<.001)$, and total sleep time with $\mathrm{S}_{\mathrm{pO}_{2}}<90 \%(P<.001)$ were significantly higher in subjects with OHS. Sleep efficiency $(P=.032)$, mean $\mathrm{S}_{\mathrm{pO}_{2}}(P<.001)$, and nadir $\mathrm{S}_{\mathrm{pO}_{2}}$ $(P<.001)$ were significantly decreased in subjects with OHS.

The variables that were associated with the presence of OHS (serum bicarbonate, BMI, AHI, ODI, nadir $\mathrm{S}_{\mathrm{pO}_{2}}$, time spent with $\mathrm{S}_{\mathrm{pO}_{2}}<90 \%$ ) were examined by logistic regression analysis. Multiple logistic regression analysis showed that serum bicarbonate levels and nocturnal nadir $\mathrm{S}_{\mathrm{pO}_{2}}$ were the independent predictive factors for OHS. There was a collinearity between AHI, ODI, lowest $\mathrm{S}_{\mathrm{pO}_{2}}$, and sleep time spent with $\mathrm{S}_{\mathrm{pO}_{2}}<90 \%$. When we removed AHI from the analysis, the result did not change. The area under the receiver operating characteristic curve for serum bicarbonate levels was 0.77 . In the receiver operating characteristic analysis, using a serum bicarbonate level of $\geq 27 \mathrm{mmol} / \mathrm{L}$ as the cutoff gives a satisfactory discrimination in class II and III obese subjects for OHS diagnosis (sensitivity of $76.6 \%$, specificity of $74.6 \%$, positive predictive value of $54.5 \%$, negative predictive value of $88.9 \%$ ). Table 3 gives the predictive parameters of different serum bicarbonate levels for identifying subjects with OHS.

For all 152 subjects, serum bicarbonate levels correlated with age $(\mathrm{r}=.23, P=.003)$, BMI $(\mathrm{r}=.19, P=.02)$, neck circumference $(\mathrm{r}=.19, P=.02)$, waist circumference $(\mathrm{r}=.24, P=.003)$, hip circumference $(\mathrm{r}=.19, P=.02)$, daytime $\mathrm{P}_{\mathrm{aO}_{2}}(\mathrm{r}=-0.19, P=.02), \mathrm{P}_{\mathrm{aCO}_{2}}(\mathrm{r}=.52, P<.001)$, $\mathrm{S}_{\mathrm{aO}_{2}}(\mathrm{r}=-0.32, P<.001), \mathrm{ABG}$ bicarbonate levels $(\mathrm{r}=.43, P<.001)$, ODI $(\mathrm{r}=.22, P=.007)$, mean $\mathrm{S}_{\mathrm{pO}_{2}}$ $(\mathrm{r}=-0.17, P=.033)$, nadir $\mathrm{S}_{\mathrm{pO}_{2}}(\mathrm{r}=-0.30, P<.001)$, and time spent with $\mathrm{S}_{\mathrm{pO}_{2}}<90 \%(\mathrm{r}=.27, P=.001)$. No correlation was found between $\mathrm{AHI}$ and serum bicarbon- 


\section{PREDICTORS OF OHS IN OSA}

Table 1. Demographics, Spirometric Measurements, ESS Scores, and ABG of Study Groups

\begin{tabular}{|c|c|c|c|}
\hline & Subjects With OHS $(n=64)$ & Subjects With Pure OSA $(n=88)$ & $P$ \\
\hline Age, y & $51.4 \pm 10.3$ & $49.7 \pm 10.9$ & .27 \\
\hline Males/females, $n$ & $28 / 36$ & $50 / 37$ & .059 \\
\hline Smoking history, $\%$ & 54.6 & 44.3 & .20 \\
\hline BMI (mean $\pm \mathrm{SD}), \mathrm{kg} / \mathrm{m}^{2}$ & $41.3 \pm 6.2$ & $39.2 \pm 5.0$ & .02 \\
\hline Neck circumference (mean $\pm \mathrm{SD}), \mathrm{cm}$ & $42.2 \pm 4.1$ & $40 \pm 3.7$ & $<.001$ \\
\hline Waist circumference (mean $\pm \mathrm{SD}$ ), $\mathrm{cm}$ & $123.0 \pm 12.9$ & $116.1 \pm 10.4$ & $<.001$ \\
\hline Hip circumference (mean $\pm \mathrm{SD}$ ), $\mathrm{cm}$ & $126.7 \pm 12.7$ & $124.2 \pm 11.3$ & .20 \\
\hline Waist/hip ratio (mean $\pm \mathrm{SD}$ ) & $0.974 \pm 0.1$ & $0.938 \pm 0.9$ & .02 \\
\hline Comorbidity, $\%$ & 85.9 & 82.9 & .40 \\
\hline Hypertension & 50 & 47.7 & .46 \\
\hline Hyperlipidemia & 54.6 & 48.8 & .29 \\
\hline Diabetes mellitus & 31.2 & 29.5 & .46 \\
\hline Ischemic heart disease & 7.8 & 7.9 & .61 \\
\hline Cerebrovascular disease & 0 & 2.2 & .34 \\
\hline $\mathrm{FVC}($ mean $\pm \mathrm{SD}), \%$ predicted & $97.6 \pm 17.7$ & $101.1 \pm 17.8$ & .25 \\
\hline $\mathrm{FEV}_{1}($ mean $\pm \mathrm{SD}), \%$ predicted & $97.4 \pm 18.5$ & $99 \pm 18.6$ & .59 \\
\hline $\mathrm{FEV}_{1} / \mathrm{FVC}($ mean $\pm \mathrm{SD})$ & $0.83 \pm 0.05$ & $0.82 \pm 0.04$ & .27 \\
\hline ESS score (mean $\pm \mathrm{SD})$ & $8.5 \pm 5.6$ & $6.6 \pm 5.9$ & .036 \\
\hline Daytime $\mathrm{P}_{\mathrm{aO}_{2}}($ mean $\pm \mathrm{SD}), \mathrm{mm} \mathrm{Hg}$ & $73.9 \pm 10.9$ & $82.1 \pm 8.5$ & $<.001$ \\
\hline Daytime $\mathrm{P}_{\mathrm{aCO}_{2}}($ mean $\pm \mathrm{SD}), \mathrm{mm} \mathrm{Hg}$ & $49 \pm 4.1$ & $41.4 \pm 2.6$ & $<.001$ \\
\hline $\begin{array}{l}\text { Daytime ABG bicarbonate (mean } \pm \mathrm{SD}) \\
\mathrm{mmol} / \mathrm{L}\end{array}$ & $25.7 \pm 2$ & $24.4 \pm 1.3$ & $<.001$ \\
\hline Serum bicarbonate (mean $\pm \mathrm{SD}$ ), $\mathrm{mmol} / \mathrm{L}$ & $27.3 \pm 2.5$ & $24.8 \pm 2.2$ & $<.001$ \\
\hline $\begin{array}{l}\text { ESS }=\text { Epworth Sleepiness Scale } \\
\text { ABG }=\text { arterial blood gas } \\
\text { OHS = obesity hypoventilation syndrome } \\
\text { OSA = obstructive sleep apnea } \\
\text { BMI = body mass index }\end{array}$ & & & \\
\hline
\end{tabular}

ate levels. No difference was observed in serum bicarbonate levels at different OSA stages.

For subjects with only OHS, serum bicarbonate levels correlated with age $(\mathrm{r}=.38, P=.002)$, BMI $(\mathrm{r}=.28$, $P=.03)$, hip circumference $(\mathrm{r}=.32, P=.01)$, daytime $\mathrm{P}_{\mathrm{aCO}_{2}}(\mathrm{r}=.34, P=.005)$, daytime $\mathrm{S}_{\mathrm{aO}_{2}}(\mathrm{r}=-0.26$, $P=.041)$, and ABG bicarbonate levels $(\mathrm{r}=.42, P=.001)$.

Most of the subjects with OHS $(82.8 \%)$ had a nadir $\mathrm{S}_{\mathrm{pO}_{2}}$ of $<80 \%$. A nadir $\mathrm{S}_{\mathrm{pO}_{2}}$ of $<80 \%$ as the cutoff gives a satisfactory discrimination in class II and III obese subjects for the diagnosis of OHS (sensitivity of $82.8 \%$, specificity of $54.5 \%$, positive predictive value of $56.9 \%$, negative predictive value of $81.4 \%$ ). When we use a serum bicarbonate level of $\geq 27 \mathrm{mmol} / \mathrm{L}$ and/or a nadir $\mathrm{S}_{\mathrm{pO}_{2}}$ of $<80 \%$ as a screening measure, we missed only 3 of 64 subjects with OHS.

For all 152 subjects, the nadir $\mathrm{S}_{\mathrm{pO}_{2}}$ correlated with neck circumference $(\mathrm{r}=-0.28, P<.001)$, waist circumference $(\mathrm{r}=-0.30, P<.001)$, waist/hip ratio $(\mathrm{r}=-0.18$, $P=.02)$, ESS scores $(\mathrm{r}=-0.23, P=.005)$, daytime $\mathrm{P}_{\mathrm{aO}_{2}}$ $(\mathrm{r}=.21, P=.01)$, daytime $\mathrm{P}_{\mathrm{aCO}_{2}}(\mathrm{r}=-0.48, P<.001)$, $\mathrm{S}_{\mathrm{aO}_{2}}(\mathrm{r}=.27, P=.001)$, ABG bicarbonate levels (r $=-0.21, P=.01)$, AHI $(\mathrm{r}=-0.59, P<.001)$, ODI (r $=-0.69, P<.001)$, mean $\mathrm{S}_{\mathrm{pO}_{2}}(\mathrm{r}=.55, P<.001)$, and time spent with $\mathrm{S}_{\mathrm{pO}_{2}}<90 \%(\mathrm{r}=-0.69, P<.001)$. For only subjects with OHS, the nadir $\mathrm{S}_{\mathrm{pO}_{2}}$ correlated with daytime $\mathrm{P}_{\mathrm{aCO}_{2}}(\mathrm{r}=-0.32, P=.009)$, AHI $(\mathrm{r}=-0.59$, $P<.001)$, ODI $(\mathrm{r}=-0.66, P<.001)$, mean $\mathrm{S}_{\mathrm{pO}_{2}}(\mathrm{r}=.47$, $P<.001)$, and time spent with $\mathrm{S}_{\mathrm{pO}_{2}}<90 \%(\mathrm{r}=-0.65$, $P<.001)$.

\section{Discussion}

In this study, we prospectively investigated the clinical predictors of OHS in obese subjects with OSA. OHS prevalence in patients with OSA varies from 11 to $38 \% .^{2,7-14,22-25}$ The prevalence increases with obesity severity. In our study, OHS prevalence was $42.1 \%$ in OSA subjects with class II and III obesity, which is higher than in previous studies. $^{2,8-14,22-25}$ The mean BMI of our subjects was higher than in most previous studies. ${ }^{9-12,14,23-25}$ This might be the reason for our higher rate. However, the frequency of OHS in our study was also higher than in previous studies with a mean BMI of $>40 \mathrm{~kg} / \mathrm{m}^{2} .2,8,13,22$ The largest OHS study in the literature was retrospective, and the prevalence of OHS was $11 \% .^{12}$ In that study, the prevalence was $24 \%$ in 


\section{PREDICTORS OF OHS IN OSA}

Table 2. Polysomnographic Data of Study Groups

\begin{tabular}{|c|c|c|c|}
\hline & $\begin{array}{l}\text { Subjects } \\
\text { With OHS } \\
(n=64)\end{array}$ & $\begin{array}{c}\text { Subjects } \\
\text { With Pure } \\
\text { OSA }(n=88)\end{array}$ & $P$ \\
\hline Sleep efficiency (mean \pm SD), $\%$ & $86.0 \pm 8.8$ & $82.5 \pm 10.6$ & .03 \\
\hline $\begin{array}{l}\text { Total sleep time (mean } \pm \mathrm{SD}) \text {, } \\
\min \end{array}$ & $438.8 \pm 58.1$ & $427.8 \pm 67.8$ & .29 \\
\hline Stages I and II (mean \pm SD), \% & $71.8 \pm 15.3$ & $68.4 \pm 15.2$ & .18 \\
\hline Stage III (mean $\pm \mathrm{SD}), \%$ & $19.4 \pm 12.3$ & $21.9 \pm 12.9$ & .24 \\
\hline $\operatorname{REM}($ mean $\pm \mathrm{SD}), \%$ & $8.9 \pm 6.5$ & $9.8 \pm 6.9$ & .42 \\
\hline $\mathrm{AHI} / \mathrm{h}($ mean $\pm \mathrm{SD})$ & $47.0 \pm 29.6$ & $35.3 \pm 24.1$ & .01 \\
\hline NREM AHI/h (mean \pm SD) & $46.6 \pm 31.1$ & $34.8 \pm 25.1$ & .01 \\
\hline $\mathrm{REM} \mathrm{AHI} / \mathrm{h}($ mean $\pm \mathrm{SD})$ & $44.5 \pm 26.8$ & $35.9 \pm 24.2$ & .06 \\
\hline $\mathrm{AI} / \mathrm{h}($ mean $\pm \mathrm{SD})$ & $31.6 \pm 31.6$ & $21 \pm 22.5$ & .004 \\
\hline $\mathrm{HI} / \mathrm{h}($ mean $\pm \mathrm{SD})$ & $11.4 \pm 12.1$ & $14.0 \pm 10.6$ & .19 \\
\hline Mild OSA, \% & 18.7 & 19.3 & $>.99$ \\
\hline Moderate OSA, $\%$ & 20.3 & 35.2 & .07 \\
\hline Severe OSA, $\%$ & 60.9 & 45.4 & \\
\hline Arousal index $($ mean $\pm \mathrm{SD})$ & $23.8 \pm 16.8$ & $22.8 \pm 15.5$ & .69 \\
\hline Mean $\mathrm{S}_{\mathrm{pO}_{2}}($ mean $\pm \mathrm{SD}), \%$ & $90.2 \pm 7.7$ & $94.4 \pm 2.3$ & $<.001$ \\
\hline Nadir $\mathrm{S}_{\mathrm{pO}_{2}}($ mean $\pm \mathrm{SD}), \%$ & $64.2 \pm 18.1$ & $78.1 \pm 10.2$ & $<.001$ \\
\hline $\mathrm{ODI} / \mathrm{h}($ mean $\pm \mathrm{SD})$ & $55.4 \pm 31.2$ & $34.3 \pm 26.3$ & $<.001$ \\
\hline NREM ODI/h $($ mean \pm SD) & $55.4 \pm 32.0$ & $34.1 \pm 27.2$ & $<.001$ \\
\hline $\mathrm{REM}$ ODI/h (mean $\pm \mathrm{SD})$ & $52.8 \pm 27.5$ & $36.1 \pm 24.6$ & .001 \\
\hline $\begin{array}{l}\text { Sleep time spent with } \mathrm{S}_{\mathrm{pO}_{2}} \\
\quad<90 \%(\text { mean } \pm \mathrm{SD}), \%\end{array}$ & $32.5 \pm 30.8$ & $10 \pm 16.1$ & $<.001$ \\
\hline $\begin{array}{l}\text { OHS = obesity hypoventilation syndrome } \\
\text { OSA = obstructive sleep apnea } \\
\text { REM = rapid eye movement } \\
\text { AHI = apnea-hypopnea index } \\
\text { NREM = non-rapid eye movement } \\
\text { AI = apnea index } \\
\text { HI = hypopnea index } \\
\text { ODI = oxygen desaturation index }\end{array}$ & & & \\
\hline
\end{tabular}

Table 3. Predictive Parameters for Serum Bicarbonate Levels in Obesity Hypoventilation Syndrome

\begin{tabular}{llll}
\hline \hline & \multicolumn{3}{c}{ Serum bicarbonate } \\
\cline { 2 - 4 } & $\geq 26 \mathrm{mmol} / \mathrm{L}$ & $\geq 27 \mathrm{mmol} / \mathrm{L}$ & $\geq 28 \mathrm{mmol} / \mathrm{L}$ \\
\hline $\begin{array}{l}\text { Sensitivity, \% } \\
\text { Specificity, \% }\end{array}$ & $60.5(48.6-71.5)$ & $76.6(62-87.7)$ & $81.2(63.5-92.7)$ \\
$\begin{array}{l}\text { Positive predictive } \\
\text { value, \% }\end{array}$ & $69.7(57.4-85.7)$ & $74.6(65.7-82.1)$ & $69.9(61.4-77.6)$ \\
$\begin{array}{l}\text { Negative predictive } \\
\quad 69.7(69.6-78.5)\end{array}$ & $54.5(41.8-66.8)$ & $39.4(27.6-52.2)$ \\
$\quad$ value, \% & & & \\
Odds ratio & $5.3(2.7-10.4)$ & $9.6(4.3-21.2)$ & $10.1(3.8-26.4)$ \\
\hline
\end{tabular}

subjects with a BMI above $40 \mathrm{~kg} / \mathrm{m}^{2} .^{12}$ There are few prospective studies, and OHS prevalence in these studies is between $13 \%$ and $37 \% .^{2,8,13,23}$

Patients with OHS have higher mortality than pure OSA patients with a similar degree of obesity. ${ }^{26,27}$ Hospitalization rates and use of health-care service requirements are also high for these patients. 5,6 Therefore, identifying pa- tients with OHS is important. However, there are few studies that evaluated the clinical differences between OHS and OSA. ${ }^{8,14,24}$ According to one of these studies, subjects with OHS were significantly younger and heavier and had lower $\mathrm{P}_{\mathrm{aO}_{2}}$ and higher $\mathrm{P}_{\mathrm{aCO}}$ than subjects with OSA and had more severe restrictive defects on spirometry. ${ }^{8}$ On the other hand, Trakada et al ${ }^{14}$ reported that subjects with OHS were older and did not differ in terms of pulmonary function compared with non-subjects with OHS. They also reported that subjects with OHS were more obese and more somnolent; had higher neck, waist, and hip circumferences and waist/hip ratios; had lower $\mathrm{P}_{\mathrm{aO}_{2}}, \mathrm{P}_{\mathrm{aCO}_{2}}$, and mean and nadir $\mathrm{S}_{\mathrm{pO}_{2}}$ during sleep; and spent more time with $\mathrm{S}_{\mathrm{pO}_{2}}<90 \%$ during sleep. ${ }^{14}$ Macavei et al ${ }^{25}$ compared the data of subjects with OHS and normocapnic obese subjects. They reported that subjects with OHS were older and heavier and had higher anthropometric measurements, lower spirometric values, and worse ABG and nocturnal oxygenation parameters (ODI, mean and nadir $\mathrm{S}_{\mathrm{pO}_{2}}$, time spent with $\mathrm{S}_{\mathrm{pO}_{2}}<90 \%$ ). In a recent study, Basoglu and Tasbakan $^{24}$ showed that subjects with OHS had higher rates of daytime sleepiness; decreased $\mathrm{FVC}, \mathrm{FEV}_{1}$, and $\mathrm{P}_{\mathrm{aO}}$; and increased $\mathrm{ABG} \mathrm{P}_{\mathrm{aCO}_{2}}$ and bicarbonate levels. Mean and nadir $\mathrm{S}_{\mathrm{pO}_{2}}$ during sleep were decreased, and sleep time spent with $\mathrm{S}_{\mathrm{pO}_{2}}<90 \%$ was increased in subjects with OHS. Our findings are consistent with the previous studies. Our subjects with OHS had higher BMI, neck circumference, waist circumference, waist/hip ratio, ESS scores, daytime ABG bicarbonate levels, AHI, ODI, and total sleep time with $\mathrm{S}_{\mathrm{pO}_{2}}<90 \%$ compared with subjects with pure OSA. Mean and nadir $\mathrm{S}_{\mathrm{pO}_{2}}$ were significantly decreased in subjects with OHS.

The most common comorbidities in OHS are hypertension, diabetes mellitus, hyperlipidemia, congestive heart failure, and gastroesophageal reflux disease. ${ }^{14,24,25}$ Similarly, the most common comorbidities were hyperlipidemia, hypertension, and diabetes mellitus in our subjects with OHS $(54.6 \%, 50 \%$, and $31.2 \%$, respectively). However, there was no significant difference in comorbidities between subjects with OHS and pure OSA.

In terms of the invasive nature of ABG analysis, identification of simple and noninvasive predictors of OHS is important. Studies evaluating the clinical predictors of $\mathrm{OHS}$ reported that higher BMI and AHI and lower $\mathrm{FEV}_{1}, \mathrm{FVC}$, daytime $\mathrm{P}_{\mathrm{aO}_{2}}$, mean and nadir nocturnal $\mathrm{S}_{\mathrm{pO}_{2}}$, sleep time spent with $\mathrm{S}_{\mathrm{pO}_{2}}<90 \%$, and $\mathrm{ABG}$ and serum bicarbonate levels are predictors of hypercapnia. ${ }^{2,8-10,12,13,24,25,28}$ Most of these studies did not provide particular thresholds that may be useful in clinical practice to predict OHS. In a few of these studies, bicarbonate levels were found to be related to OHS diagnosis..$^{2,24,25}$

In OSA, recurrent upper airway obstruction can lead to acute intermittent hypercapnia during sleep. ${ }^{29-33}$ When obstructive events are too long and repetitive, compensation 


\section{PREDICTORS OF OHS IN OSA}

failure occurs and leads to excessive hypercapnia. Nocturnal intermittent hypercapnia in OSA leads to renal bicarbonate retention to compensate for acute respiratory acidosis. ${ }^{33,34}$

As we know, patients with OHS have both obstructive events and severe hypoventilation during sleep, which lead to daytime hypercapnia. In the light of these data, patients with OHS should have high serum bicarbonate levels. Additionally, we do not expect high serum bicarbonate levels in patients with OSA. We speculated that serum bicarbonate levels should differentiate subjects with OHS from subjects with pure OSA. Three studies showed that increased bicarbonate levels are a sensitive screening measure for daytime hypercapnia, but 2 of these studies used ABG bicarbonate, not serum bicarbonate. ${ }^{2,24,25}$

In the literature, there is only one study that evaluated serum bicarbonate. ${ }^{2}$ This study revealed that serum bicarbonate levels $(P<.001)$, AHI $(P=.006)$, and nocturnal nadir $\mathrm{S}_{\mathrm{pO}_{2}}(P<.001)$ were independent predictive factors of OHS. ${ }^{2}$ That study selected a threshold of $27 \mathrm{mmol} / \mathrm{L}$ for serum bicarbonate and found a sensitivity of $92 \%$ and a specificity of $50 \%$. When combining serum bicarbonate levels of $>27 \mathrm{mmol} / \mathrm{L}$ and $\mathrm{AHI}>100$ as screening measures, only $3 \%$ of subjects with OHS were missed. ${ }^{2}$ Our findings for bicarbonate were consistent with that study, but AHI was not a predictor of OHS in our study. We found that serum bicarbonate levels and nocturnal nadir saturation were the predictive factors related to OHS.

The mean BMI and AHI of subjects in the study of Mokhlesi and Tulaimat ${ }^{2}$ were higher than those of our subjects. This might be the reason that we did not find AHI to a predictor in our study. However, Mokhlesi and Tulaimat ${ }^{2}$ used only BMI, $\mathrm{AHI}$, nadir $\mathrm{S}_{\mathrm{pO}_{2}}$, and serum bicarbonate levels as potential variables for OHS prediction. In contrast, we used BMI, AHI, ODI, nadir $\mathrm{S}_{\mathrm{pO}_{2}}$, and sleep time spent with $\mathrm{S}_{\mathrm{pO}_{2}}<90 \%$. This might explain why we did not find AHI to be a predictor of OHS in our study. There was a collinearity between AHI, ODI, nadir $\mathrm{S}_{\mathrm{pO}_{2}}$, and sleep time spent with $\mathrm{S}_{\mathrm{pO}_{2}}<90 \%$, but when we removed AHI from the analysis, the result did not change. In our study, serum bicarbonate levels $\geq 27 \mathrm{mmol} / \mathrm{L}$ had a sensitivity of $76.6 \%$, a specificity of $74.6 \%$, a positive predictive value of $54.5 \%$, and a negative predictive value of $88.9 \%$. Additionally, a nadir $\mathrm{S}_{\mathrm{pO}_{2}}$ of $<80 \%$ had a sensitivity of $82.8 \%$, a specificity of $54.5 \%$, a positive predictive value of $56.9 \%$, and a negative predictive value of $81.4 \%$. When we use serum bicarbonate levels $\geq 27 \mathrm{mmol} / \mathrm{L}$ and/or a nadir $\mathrm{S}_{\mathrm{pO}_{2}}$ of $<80 \%$ as a screening measure, 3 of 64 subjects with OHS were missed.

In the study of Basoglu and Tasbakan, ${ }^{24}$ hypercapnia was found to be associated independently with ABG bicarbonate levels and $\mathrm{S}_{\mathrm{aO}}$. Bicarbonate levels $\geq 27 \mathrm{mmol} / \mathrm{L}$ had a sensitivity of $88.1 \%$ and a specificity of $73.1 \%$, and an $\mathrm{S}_{\mathrm{aO}_{2}}$ of $\leq 95 \%$ had a sensitivity of $64.4 \%$ and a spec- ificity of $73.9 \%$ for identifying OHS. ${ }^{24}$ Macavei et al ${ }^{25}$ reported that $\mathrm{P}_{\mathrm{aO}_{2}}$ and $\mathrm{ABG}$ bicarbonate levels were independent predictors of OHS and that bicarbonate $>27 \mathrm{mmol} / \mathrm{L}$ had an $85.7 \%$ sensitivity and an $89.5 \%$ specificity for diagnosis of OHS, with a $68.1 \%$ positive predictive value and a $95.9 \%$ negative predictive value.

Our study showed that serum bicarbonate levels were significantly higher in subjects with OHS compared with subjects with pure OSA. However, no correlation was found between AHI and serum bicarbonate levels. No difference was observed between bicarbonate levels at different OSA stages. Additionally, we found a moderate correlation between serum bicarbonate and daytime ABG bicarbonate levels, $\mathrm{P}_{\mathrm{aCO}_{2}}$, and $\mathrm{S}_{\mathrm{aO}_{2}}$. According to these findings, elevated serum bicarbonate levels can be helpful in identifying patients with OHS.

OHS can be diagnosed only after other causes of hypercapnia have been excluded. In some previous studies, respiratory comorbidities causing hypercapnia were not exclusion criteria. ${ }^{8}, 12$ Excluding respiratory diseases that might cause hypercapnia and a study sample with a definite diagnosis of OHS are strong points of our study. The presence of COPD is a confusing factor for OHS prevalence. ${ }^{35}$ The prevalence of daytime hypercapnia in patients with OSA is higher when associated with COPD. ${ }^{12}$ Similar results were reported by Chaouat et al. ${ }^{36}$ The prevalence of daytime hypercapnia was $27 \%$ in subjects with OSA and COPD and $8 \%$ in subjects with OSA only. In our study, all subjects had spirometric and ABG results, and we excluded subjects with COPD. Excluding OHS subjects without OSA and using a homogenous group are additional strong points of our study.

Nevertheless, there are some limitations of our study. Our study group did not include class I obese subjects. We aimed to find more OHS subjects, so we selected class II and III obese subjects. We could not use end-tidal $\mathrm{CO}_{2}$ measurements or capnography. However, we think that the OHS prevalence in our study would be greater whether we performed end-tidal $\mathrm{CO}_{2}$ measurements or capnography.

\section{Conclusions}

OHS is common in class II and III obese patients with OSA. Serum bicarbonate levels $\geq 27 \mathrm{mmol} / \mathrm{L}$ and a nadir $\mathrm{S}_{\mathrm{pO}_{2}}$ of $<80 \%$ in OSA patients with class II and III obesity should prompt clinicians to measure $\mathrm{ABG}$ to confirm the presence of hypercapnia. Serum bicarbonate is a reasonable screening measure for hypercapnia, especially because it is less invasive than an arterial puncture. More studies should be done to determine the place of serum bicarbonate and nocturnal nadir $\mathrm{S}_{\mathrm{pO}_{2}}$ in the diagnosis of OHS and threshold levels. 


\section{PREDICTORS OF OHS IN OSA}

\section{REFERENCES}

1. Olson AL, Zwillich C. The obesity hypoventilation syndrome. Am J Med 2005;118(9):948-956.

2. Mokhlesi B, Tulaimat A. Obesity hypoventilation syndrome: prevalence and predictors in patients with obstructive sleep apnea. Sleep Breath 2007;11(2):117-124.

3. Hida W. Quality of life in obesity hypoventilation syndrome. Sleep Breath 2003;7(1):1-2.

4. Hida W, Okabe S, Tatsumi K, Kimura H, Akasiba T, Chin K, et al. Nasal continuous positive airway pressure improves quality of life in obesity hypoventilation syndrome. Sleep Breath 2003;7(1):3-12.

5. Berg G, Delaive K, Manfreda J, Walld R, Kryger MH. The use of health-care resources in obesity-hypoventilation syndrome. Chest 2001;120(2):377-383.

6. Jennum P, Kjellberg J. Health, social and economical consequences of sleep disordered breathing: a controlled national study. Thorax 2011;66(7):560-566.

7. Mokhlesi B. Obesity hypoventilation syndrome: a state-of the-art review. Respir Care 2010;55(10):1347-1362; discussion 1363-1365.

8. Resta O, Foschino Barbaro MP, Bonfitto P, Talamo S, Mastrosimone V, Stefano A, Giliberti T. Hypercapnia in obstructive sleep apnoea syndrome. Neth J Med 2000;56(6):215-222.

9. Akashiba T, Kawahara S, Kosaka N, Ito D, Saito O, Majima T, Horie T. Determinants of chronic hypercapnia in Japanese men with obstructive sleep apnea syndrome. Chest 2002;121(2):415-421.

10. Golpe R, Jiménez A, Carpizo R. Diurnal hypercapnia in patients with obstructive sleep apnea syndrome. Chest 2002;122(3):1100-1101; author reply 1101 .

11. Verin E, Tardif C, Pasquis P. Prevalence of daytime hypercapnia or hypoxia in patients with OSAS and normal lung function. Respir Med 2001;95(8):693-696.

12. Laaban JP, Chailleux E. Daytime hypercapnia in adult patients with obstructive sleep apnea syndrome in France, before initiating nocturnal nasal continuous positive airway pressure therapy. Chest 2005; 127(3):710-715

13. Leech JA, Onal E, Baer P, Lopata M. Determinants of hypercapnia in occlusive sleep apnea syndrome. Chest 1987;92(5):807-813.

14. Trakada GP, Steiropoulos P, Nena E, Constandinidis TC, Bouros D. Prevalence and clinical characteristics of obesity hypoventilation syndrome among individuals reporting sleep-related breathing symptoms in northern Greece. Sleep Breath 2010;14(4):381-386.

15. Berger KI, Ayappa I, Chatr-Amontri B, Marfatia A, Sorkin IB, Rapoport DM, Goldring RM. Obesity hypoventilation syndrome as a spectrum of respiratory disturbances during sleep. Chest 2001;120(4): 1231-1238.

16. Khosla $\mathrm{T}$, Lowe $\mathrm{CR}$. Indices of obesity derived from body weight and height. Br J Prev Soc Med 1967;21(3):122-128.

17. American Thoracic Society. Standardization of spirometry, 1994 update. Am J Respir Crit Care Med 1995;152(3):1107-1136.

18. Polysomnography Task Force, American Sleep Disorders Association Standards of Practice Committee. Practice parameters for the indications for polysomnography and related procedures. Sleep 1997; 20(6):406-422.

19. Iber C, Ancoli-Israel S, Stuart Quan M. AASM manual for the scoring of sleep and associated events: rules, terminology, and technical specifications. Westchester, IL: American Academy of Sleep Medicine; 2007.
20. American Academy of Sleep Medicine. International classification of sleep disorders: diagnostic and coding manual, 2nd edition. Westchester, IL: American Academy of Sleep Medicine; 2005.

21. Piper AJ, Grunstein RR. Obesity hypoventilation syndrome: mechanisms and management. Am J Respir Crit Care Med 2011;183(3): 292-298.

22. Nowbar S, Burkart KM, Gonzales R, Fedorowicz A, Gozansky WS, Gaudio JC, et al. Obesity-associated hypoventilation in hospitalized patients: prevalence, effects, and outcome. Am J Med 2004;116(1): 1-7.

23. Kessler R, Chaouat A, Schinkewitch P, Faller M, Casel S, Krieger J, Weitzenblum E. The obesity-hypoventilation syndrome revisited: a prospective study of 34 consecutive cases. Chest 2001;120(2):369376

24. Basoglu OK, Tasbakan MS. Comparison of clinical characteristics in patients with obesity hypoventilation syndrome and obese obstructive sleep apnea syndrome: a case-control study. Clin Respir J 2014; 8(2):167-174.

25. Macavei VM, Spurling KJ, Loft J, Makker HK. Diagnostic predictors of obesity-hypoventilation syndrome in patients suspected of having sleep disordered breathing. J Clin Sleep Med 2013;9(9):879884

26. Carden KA, Fogel RB. Obesity-associated hypoventilation-a "growing" concern. Am J Med 2004;116(1):58-59.

27. Javaheri S, Colangelo G, Lacey W, Gartside PS. Chronic hypercapnia in obstructive sleep apnea-hypopnea syndrome. Sleep 1994;17(5): 416-423.

28. Kaw R, Hernandez AV, Walker E, Aboussouan L, Mokhlesi B. Determinants of hypercapnia in obese patients with obstructive sleep apnea: a systematic review and metaanalysis of cohort studies. Chest 2009;136(3):787-796.

29. Resta O, Foschino-Barbaro MP, Bonfitto P, Talamo S, Legari G, De Pergola G, et al. Prevalence and mechanisms of diurnal hypercapnia in a sample of morbidly obese subjects with obstructive sleep apnoea. Respir Med 2000;94(3):240-246.

30. Ayappa I, Berger KI, Norman RG, Oppenheimer BW, Rapoport DM, Goldring RM. Hypercapnia and ventilatory periodicity in obstructive sleep apnea syndrome. Am J Respir Crit Care Med 2002;166(8): $1112-1115$

31. Adrogue HJ, Madias NE. Arterial blood gas monitoring: acid base assessment. In: Tobin MJ. Principles and practice of intensive care monitoring. New York: McGraw-Hill; 1998:217-241.

32. Madias NE, Wolf CJ, Cohen JJ. Regulation of acid-base equilibrium in chronic hypercapnia. Kidney Int 1985;27(3):538-543.

33. Berger KI, Ayappa I, Sorkin IB, Norman RG, Rapoport DM, Goldring RM. Postevent ventilation as a function of $\mathrm{CO}_{2}$ load during respiratory events in obstructive sleep apnea. J Appl Physiol 2002;93(3): 917-924.

34. Berger KI, Goldring RM, Rapoport DM. Obesity hypoventilation syndrome. Semin Respir Crit Care Med 2009;30(3):253-261.

35. Bradley TD, Rutherford R, Lue F, Moldofsky H, Grossman RF, Zamel N, Phillipson EA. Role of diffuse airway obstruction in the hypercapnia of obstructive sleep apnea. Am Rev Respir Dis 1986; 134(5):920-924.

36. Chaouat A, Weitzenblum E, Krieger J, Ifoundza T, Oswald M, Kessler R. Association of chronic obstructive pulmonary disease and sleep apnea syndrome. Am J Respir Crit Care Med 1995;151(1):8286. 